\title{
Supplemental Oxygen in the Newborn: Historical Perspective and Current Trends
}

\author{
Maxwell Mathias 1,*®D, Jill Chang ${ }^{2,3}$, Marta Perez ${ }^{2,3}$ and Ola Saugstad ${ }^{2,4}$ \\ 1 Center for Pregnancy and Newborn Research, Department of Pediatrics, Section of Neonatal-Perinatal \\ Medicine, University of Oklahoma Health Sciences Center, Oklahoma City, OK 73104, USA \\ 2 Division of Neonatology, Department of Pediatrics, Northwestern University Feinberg School of Medicine, \\ Chicago, IL 60611, USA; jchang@luriechildrens.org (J.C.); mtperez@luriechildrens.org (M.P.); \\ o.d.saugstad@medisin.uio.no (O.S.) \\ 3 Ann \& Robert H. Lurie Children's Hospital of Chicago, Chicago, IL 60611, USA \\ 4 Department of Pediatric Research, University of Oslo, N-0424 Oslo, Norway \\ * Correspondence: maxwell-mathias@ouhsc.edu; Tel.: +1-405-271-5215; Fax: +1-405-271-1236
}

Citation: Mathias, M.; Chang, J.; Perez, M.; Saugstad, O. Supplemental Oxygen in the Newborn: Historical Perspective and Current Trends. Antioxidants 2021, 10, 1879. https:// doi.org/10.3390/antiox10121879

Academic Editors: Julia Kuligowski and Máximo Vento

Received: 14 October 2021

Accepted: 23 November 2021

Published: 25 November 2021

Publisher's Note: MDPI stays neutral with regard to jurisdictional claims in published maps and institutional affiliations.

Copyright: (c) 2021 by the authors. Licensee MDPI, Basel, Switzerland. This article is an open access article distributed under the terms and conditions of the Creative Commons Attribution (CC BY) license (https:// creativecommons.org/licenses/by/ $4.0 /)$.

\begin{abstract}
Oxygen is the final electron acceptor in aerobic respiration, and a lack of oxygen can result in bioenergetic failure and cell death. Thus, administration of supplemental concentrations of oxygen to overcome barriers to tissue oxygen delivery (e.g., heart failure, lung disease, ischemia), can rescue dying cells where cellular oxygen content is low. However, the balance of oxygen delivery and oxygen consumption relies on tightly controlled oxygen gradients and compartmentalized redox potential. While therapeutic oxygen delivery can be life-saving, it can disrupt growth and development, impair bioenergetic function, and induce inflammation. Newborns, and premature newborns especially, have features that confer particular susceptibility to hyperoxic injury due to oxidative stress. In this review, we will describe the unique features of newborn redox physiology and antioxidant defenses, the history of therapeutic oxygen use in this population and its role in disease, and clinical trends in the use of therapeutic oxygen and mitigation of neonatal oxidative injury.
\end{abstract}

Keywords: hyperoxia; prematurity; bronchopulmonary dysplasia; retinopathy of prematurity

\section{Introduction}

\subsection{Hyperoxia Is Damaging to Developing Organ Systems}

Mammals gestate at lower oxygen tension than their postnatal environment, and birth (even in the absence of supplemental oxygen) constitutes an increase in oxygen exposure [1]. In addition, rapid post-natal growth and development requires significant oxygen delivery and consumption per gram of tissue in newborns, and energy sources are more rapidly depleted than in adults $[2,3]$. Alterations in mitochondrial oxygen concentration can induce apoptotic cell signaling pathways through mitochondrial proton leak [4], while non-mitochondrial derived reactive oxygen and nitrogen intermediates (ROI) play an important role in intra- and inter-cellular growth factor signaling (see [5] for review). Lastly, enzymatic and non-enzymatic antioxidant systems in newborns have decreased capacity to sequester ROI [6]. Premature exposure to ambient air (fraction of inspired oxygen or $\left.\mathrm{FiO}_{2}=21 \%\right)$ and oxygen exposure above ambient air $\left(\mathrm{FiO}_{2}>21 \%\right)$ disrupts these processes.

The preterm and term newborn occupies a unique position as an organism with high tissue oxygen demand, growing and developing organ systems, and susceptibility to oxidative injury. Excess oxygen is the substrate for free radical formation by several enzymes, such as the xanthine oxidase and NADPH-oxidase families [7]. Free radicals induce membrane disruption and activation of inflammatory pathways through lipid peroxidation, affecting multiple organ systems. Elevated lipid peroxidation products have been found in plasma samples of infants with bronchopulmonary dysplasia (BPD) compared to those without [8]. In the lungs, hyperoxia exposure induces alveolar simplification and vascular 
remodeling, which is associated with disruption in the electron transport chain $[9,10]$. Hyperoxia exposure is also associated with injury and altered physiology in the developing intestines and retinopathy of prematurity (ROP), a developmental eye disease involving aberrant growth of the retinal vasculature that can result in blindness [11-13]. Lastly, neonatal hyperoxia alters cerebral blood flow, and neuronal apoptosis and inflammation have been shown after neonatal hyperoxia exposure [14-16].

\subsection{Full Term and Preterm Newborns Have Decreased Antioxidant Capacity}

Many important vitamin and mineral stores are delivered to the fetus during the third trimester of pregnancy; as a result, preterm infants have decreased levels of these important cofactors relative to term infants [17]. Plasma vitamin C levels are lower in preterm infants relative to term infants [18]. In a prospective study of vitamin D supplementation in 100 preterm infants, two-thirds had biochemical vitamin D deficiency [19]. In addition, pulmonary levels of glutathione peroxidase 1, cytosolic superoxide dismutase (SOD), mitochondrial SOD, and extracellular SOD are significantly lower in newborn mice than those at 3 and 7 weeks of age in mice. Along with decreased antioxidant expression, newborn mice exhibit increased mitochondrial oxidative stress compared to adults during hyperoxia exposure [6]. In a cohort of preterm infants with and without BPD, plasma vitamin E levels were below term infant levels, and were lower in infants with BPD than those without [20].

Given the decreased levels of antioxidant enzymes and vitamins in preterm infants, several clinical trials have been conducted to evaluate whether supplementation with either intact antioxidant enzyme or vitamin cofactors might decrease morbidity and mortality in this population. Trials of administration of exogenous SOD in the clinical setting were initially promising [21-23]; however, meta-analyses and long term follow-ups have shown no benefit over placebo [24]. Similarly, supplementation with the antioxidant cofactor vitamins A, C, and E have been studied, along with the glutathione precursor $\mathrm{N}$-acetylcysteine (NAC). Vitamin A has been the subject of extensive research with mixed results, including the largest randomized controlled trial to date entitled NeoVitaA, which has not yet published its results [25-27]. A Cochrane meta-analysis in 2016 found marginal benefit of intramuscular administration of vitamin A to prevent death or BPD (RR $0.93[0.88,0.99])$; however, intramuscular formulation is not readily available and repeat intramuscular injections pose a practical challenge in very low birth weight $(<1500 \mathrm{~g})$ infants [28]. Vitamin $\mathrm{C}, \mathrm{E}$, and NAC have also not shown clear benefit, and supplementation beyond nutritional needs is not recommended [29-34].

\subsection{ROI Are Essential Components of Cell Signaling Pathways in Development}

Despite the association of neonatal disease with ROI byproducts (e.g., lipid peroxides), the growth and development of organs and tissues relies on the production of ROI. Numerous growth factor receptors are tyrosine kinases (RTKs), whose function depends on local hydrogen peroxide derived from ROI. Peroxide oxidizes protein phosphatases (PTPs) by altering the 3-D structure and allowing RTK autophosphorylation and signal transduction $[35,36]$. Suppression of hydrogen peroxide with exogenous catalase will reduce tyrosine kinase phosphorylation and decrease growth factor signaling, which has been shown to reduce vascular endothelial cell migration $[37,38]$. In addition, increases in antioxidant capacity can impair growth and development. Inhibition of nuclear factor erythroid 2-related factor 2 (NRF2), an important transcription factor in the production of antioxidants in response to oxidative stress, increased fetal growth in a mouse model of pregnancyassociated hypertension, suggesting an important role for ROI in fetal growth [39]. A clearer picture of the complex interplay between postnatal oxygen exposure, antioxidant expression and function, and development and growth signaling is needed. 


\section{Supplemental Oxygen in the Initial Resuscitation of Newborns}

\subsection{Historical Aspects}

While the first documented use of oxygen in infants was in 1780 , just few years after its discovery, it was not until 1928 that a description of using oxygen in newborn resuscitation was published [40]. Oxygen therapy was subsequently introduced into routine newborn care in the 1930s and early 1940s. This was followed in relatively short order by the first published description of retrolental fibroplasia (RLF), a mysterious eye disease found in a small group of infants born prematurely, now known as ROP [41]. The progressive nature of this disorder was confirmed in 1948 by a husband-and-wife opthalmologist team working at Johns Hopkins University, who described development of RLF changes in a cohort of premature infants [42]. It was not until the 1950s that oxygen was identified as the culprit behind RLF, the leading cause of blindness in children of preschool age at that time [43-45]. This discovery was followed by decades of avoidance of oxygen that likely led to decreased survival of the most premature and sickest infants [46]. With the advent of oxygen saturation monitoring in the 1980s, however, oxygen therapy could be better targeted, resulting in improved survival and an associated increase in ROP once again [47].

\subsection{Supplemental Oxygen in Term Infants}

By the 1960 s, the use of $100 \%$ oxygen in the delivery room was viewed as the standard of care and the most sensible approach to resuscitation of asphyxiated infants [48]. The International Liaison Committee on Resuscitation (ILCOR), first formed in 1992 to provide a forum for major resuscitation organizations in the industrialized world, recommended the use of $100 \%$ oxygen in its first set of newborn guidelines [49]. There were published opinions against such an approach as early as 1980, based on emerging clinical and animal data that implicated delivery room hyperoxia in subsequent oxidative stress generation $[7,50]$. This included evidence of increased hypoxanthine concentrations in the cerebral cortex of hypoxemic piglets randomized to resuscitation with $100 \% \mathrm{FiO}_{2}$ compared to $21 \% \mathrm{FiO}_{2}$, suggesting the presence of more severe energy metabolism deficits in the hyperoxia-exposed group. Animal models also increasingly supported the use of $21 \%$ $\mathrm{FiO}_{2}$ during resuscitation and demonstrated that it is as effective as $100 \% \mathrm{FiO}_{2}$ in the resuscitation of hypoxemic piglets, with similar improvements in vital signs, base deficit, and plasma hypoxanthine [51,52]. Furthermore, studies in human neonates demonstrated that term newborns can be adequately resuscitated with $21 \% \mathrm{FiO}_{2}$, with lower mortality in infants exposed to $21 \%$ vs. $100 \% \mathrm{FiO}_{2}$ [53], with follow-up studies showing similar long-term neurodevelopmental outcomes [54]. Additional studies demonstrated that resuscitation with $100 \% \mathrm{FiO}_{2}$ can be harmful $[55,56]$. In term neonates with perinatal asphyxia, resuscitation with $21 \% \mathrm{FiO}_{2}$ resulted in more rapid improvements in Agpar scores and faster onset of spontaneous respiration, while infants treated with high $\mathrm{FiO}_{2}$ demonstrated evidence of increased oxidative stress at one month of age, with lower reduced-to-oxidized glutathione ratios and higher erythrocyte antioxidant enzyme activity [55]. Finally, a metaanalysis also contributed to the growing consensus; in term and late-preterm neonates in need of resuscitation at birth, $21 \% \mathrm{FiO}_{2}$ restores heart rate and spontaneous respiration as effectively as $100 \% \mathrm{FiO}_{2}$, while also being associated with significant reductions in neonatal mortality [57]. This accumulating evidence resulted in revisions to neonatal resuscitation guidelines that now recommend starting with $21 \% \mathrm{FiO}_{2}$ and caution against $100 \% \mathrm{FiO}_{2}$ in near-term and in-term infants $[58,59]$.

\subsection{Supplemental Oxygen in Preterm Infants}

Evidence for the optimal oxygen concentration in the resuscitation of preterm infants is less conclusive. The available data suggest that many preterm infants need an $\mathrm{FiO}_{2}$ somewhere between $21 \%$ and $100 \%$ during resuscitation. A recently published metaanalysis found conflicting data on the impact of initiating resuscitation with lower $(<40 \%)$ vs. higher $(\geq 40 \%) \mathrm{FiO}_{2}$ in preterm infants, with 9 out of 10 studies finding no differences in mortality [60]. Other publications, however, found an association between initiation of 
resuscitation with lower $\mathrm{FiO}_{2}$ and increased risk of death in immature preterm infants in an international cohort [61] and a Canadian cohort [62]. However, a follow-up study of the Canadian cohort at 18 to 21 months corrected age (gestational age at birth plus absolute age) found no differences in the composite outcome of death or neurodevelopmental impairment and an increased risk of severe neurodevelopmental impairment in infants who received $100 \% \mathrm{FiO}_{2}$ versus those receiving $21 \% \mathrm{FiO}_{2}$ [63]. However, preterm infants not reaching an oxygen saturation $\left(\mathrm{SpO}_{2}\right)$ of $80 \%$ within the first $5 \mathrm{~min}$ of life have been shown to have higher mortality and risk of severe IVH $[64,65]$. In addition, the combination of bradycardia and hypoxemia in the first minutes of life wasn't increases mortality. Although the optimal initial $\mathrm{FiO}_{2}$ is not fully known in these infants, it is still recommended to target a $\mathrm{SpO}_{2}$ of $80-85 \%$ within the first $5 \mathrm{~min}$ of life, as well as to avoid bradycardia (heart rate $<100 \mathrm{bpm}$ ).

\section{Supplemental Oxygen in the Neonatal ICU}

\subsection{Historical Perspective}

Beyond the delivery room, exposure to hyperoxia and oxidative stress has been associated with a multitude of adverse outcomes in infants, including ROP, BPD, and brain injury (including intraventricular hemorrhage and periventricular leukomalacia). These concerns have led to improvements in methods for measuring oxygenation in neonates, enabling a more precise titration of oxygen delivery. However, the optimal oxygen saturation target in extremely premature infants remains uncertain given the varying results in both randomized and observational studies [66]. Trials conducted in the 1950s demonstrated that administration of high $\mathrm{FiO}_{2}$ to preterm infants significantly increased their risk of severe ROP and blindness and led to the practice of restricting $\mathrm{FiO}_{2}$ in the 1960s to no more than 50\% [45,67-70]. This change was estimated to result in an excess of 16 deaths per case of blindness prevented [46]. The introduction of transcutaneous $\mathrm{PO}_{2}$ electrodes allowed for more precise and tighter control of oxygen delivery to preterm infants, and a reduction in ROP was seen in all but the lowest gestational ages. In the 1980s and 1990s, pulse oximetry became the preferred method for monitoring oxygenation, while in the early 2000s, the American Academy of Pediatrics (AAP) suggested a target $\mathrm{SpO}_{2}$ range of $85-95 \%$, which corresponds to $\mathrm{PaO}_{2}$ range of $29-67 \mathrm{~mm} \mathrm{Hg}(3.8-8.9 \mathrm{kPa})$, in oxygen-dependent preterm babies in the first 2 weeks of life [71].

\subsection{Targeted Use of Supplemental Oxygen}

In 2003, the Neonatal Oxygenation Prospective Meta-Analysis (NeOProM) collaborative study was formed to address the question of ideal oxygen targets in extremely preterm infants. The goal was to examine the effects of low versus high functional oxygen saturation targets in the postnatal period in premature infants $<28$ weeks gestation. Investigators in separate randomized clinical trials prospectively planned to undertake individual trials using similar study designs, participants, interventions, comparators, and outcomes. They agreed to provide individual participant data at trial completion for inclusion in a meta-analysis [69]. Prior to this collaborative effort, there existed only a few small randomized trials in the 1950s [44,72-74] and in the early 2000s [75] investigating oxygen targets in preterm infants. NeOProM ultimately included five multicenter studies under five study groups: Surfactant, Positive Pressure, and Pulse Oximetry Randomized Trial (SUPPORT) in the United States [76]; Benefits of Oxygen Saturation Targeting (BOOST II) trials conducted separately in the United Kingdom, Australia, and New Zealand [77-79]; and the Canadian Oxygen Trial (COT) [80]. In these 5 trials, a total of 4965 premature infants (<28 weeks gestation) were randomized to either a low (85-89\%) or high (91-95\%) $\mathrm{SpO}_{2}$ within the first $24 \mathrm{~h}$ after birth. Subsequent meta-analyses including follow-up data from the NEOPROM studies have since been published [69,81-83].

The primary outcome for each of the trials was a composite of death or disability by 18-24 months corrected age. No differences in the primary outcome were found between infants assigned to the low (85-89\%) or high (91-95\%) $\mathrm{SpO}_{2}$ range. Sub-group analysis also showed no differences for the primary outcome (death or major disability) for gestational 
age, inborn vs. outborn status, antenatal corticosteroid use, sex, small for gestational age (SGA) vs. appropriate for gestational age (AGA), singleton vs. multiple birth, type of delivery, age at the start of the intervention, or oximeter software type [84].

Despite finding no difference in primary outcome, secondary outcomes from the $\mathrm{NeOProM}$ trial raised concerns regarding the importance of oxygen exposure. A higher rate of mortality before the corrected age of 36 weeks, before hospital discharge, and prior to reaching a corrected age of 18 to 24 months was found in infants assigned to the low $\mathrm{SpO}_{2}(85-89 \%)$ target range $[69,85]$. A higher incidence of necrotizing enterocolitis (NEC) was also associated with the low $\mathrm{SpO}_{2}(85-89 \%)$ target range. In contrast, there was a lower incidence of ROP requiring treatment associated with the low $\mathrm{SpO}_{2}(85-89 \%)$ target range $[69,81-84]$. Of note, this finding showed substantial heterogeneity because SUPPORT was the only trial within NeOProM to find significant reductions in the need for ROP treatment [85]. Additionally, the increased incidence of ROP in the higher oxygen group (91-95\%) did not translate to increased severe visual impairment (defined as bilateral legal blindness) at 18 to 24 months [83]. Additional secondary outcomes including physiologic $\mathrm{BPD}$, intraventricular hemorrhage (IVH), periventricular leukomalacia (PVL), and neurodevelopmental outcomes as assessed by using the Gross Motor Function Classification System or Bayley Scales of Infant Development (BSID) did not differ between the low- and high-oxygen groups $[81,82,86]$.

One main limitation of the NeoProM trial was that significant overlap was found in the actual exposed oxygen saturation between the two groups, despite the design of the trials specifying separation between the target ranges. Although the protocols specified a distinct separation of the $\mathrm{SpO}_{2}$ target in the two groups there was significant overlap in the $\mathrm{SpO}_{2}$ achieved, resulting in poor separation between the intervention and comparison groups [82]. Poststudy analysis showed that subjects randomized to $91-95 \%$ spent $13.9-22.4 \%$ of the time with $\mathrm{SpO}_{2}>95 \%$ and subjects randomized to $85-89 \%$ spent $20.2-27.4 \%$ of the time $<85 \%$ while on supplemental oxygen [83]. An additional limitation to the NeOProM trial was that two trials (BOOST II trials in the United Kingdom and Australia) were stopped early, which may have resulted in some overestimation of the effect on mortality in these trials [84].

Following the NeOProM publications, some experts in the field suggested that functional $\mathrm{SpO}_{2}$ should be targeted at $90-95 \%$ in infants with gestational age $<28$ weeks until 36 weeks corrected age and alarm limits 89-95\% [71,81]. In 2016, the AAP released new guidelines stating that "the ideal physiologic target range for oxygen saturation for infants of extremely low birth weight is likely patient-specific, dynamic, and dependent on various factors, including gestational age, chronological age, underlying disease, and transfusion status" [86]. Additionally, these guidelines conclude that a target oxygen saturation "range of $90 \%$ to $95 \%$ may be safer than $85 \%$ to $89 \%$, at least for some infants." The 2019 European guidelines recommend "in preterm babies receiving oxygen, the saturation target should be between 90 and 94\%" and that "alarm limits should be set to 89 and 95\%" [87].

Both the SUPPORT and BOOST trials used fixed, binary $\mathrm{SpO}_{2}$ targets for the duration of study enrollment (birth to 36 weeks corrected age). It is possible that optimal oxygen saturation varies during the course of NICU hospitalization. The pathophysiology of ROP is thought to involve initial hyperoxic arrest of vascular growth followed by hypoxia-induced hyperproliferation of the retinal vasculature $[13,88,89]$. In the STOP-ROP trial, infants were enrolled at the time of diagnosis of ROP (mean 10 weeks of absolute age or 35 weeks corrected age) to receive oxygen to target $\mathrm{SpO}_{2}$ to $89-94 \%$ or $96-99 \%$. While the higher oxygen saturation target was associated with adverse pulmonary events and prolonged hospital stay, it was not associated with progression of ROP [75]. In a retrospective study comparing a static $\mathrm{SpO}_{2}$ goal to a biphasic goal that increased the target to $>95 \%$ at 34 weeks corrected, infants in the biphasic group had a lower incidence and severity of ROP without an impact on mortality [90]. 


\subsection{Persistent Pulmonary Hypertension of the Newborn}

One notable exception to the targeting of specific $\mathrm{SpO}_{2}$ in the newborn is for infants with persistent pulmonary hypertension of the newborn (PPHN). Prenatally, most of the fetal blood flow bypasses the lungs through elevated pulmonary blood pressure and rightto-left shunts at the level of the atria through the foramen ovale and the great arteries through the ductus arteriosus. During normal birth, crying and initiation of the first breaths results in a rapid decrease in pulmonary blood pressure, allowing blood to circulate through the lungs and participate in gas exchange to oxygenate the infant. When infants do not undergo this physiologic decrease in pulmonary blood pressure, they develop PPHN.

The severity of PPHN can range from mild, requiring only brief oxygen supplementation, to severe, requiring intubation, mechanical ventilation, and even cardiopulmonary bypass with extracorporeal membranous oxygenation (ECMO) [91]. Oxygen is a potent pulmonary vasodilator within the context of hypoxia [92]; as such, up to $100 \% \mathrm{FiO}_{2}$ is commonly used in the treatment of $\mathrm{PPHN}$, regardless of infant $\mathrm{SpO}_{2}$ [93]. However, there is no clear benefit and potential harm in using such high $\mathrm{FiO}_{2}$ in the treatment of PPHN. In a lamb model of meconium-aspiration-induced PPHN, pulmonary blood flow and brain oxygen delivery were maximized when targeting a $\mathrm{SpO}_{2}$ of $95-99 \%$ during a $6 \mathrm{~h}$ exposure when compared to a fixed $\mathrm{FiO}_{2}$ of $100 \%$ or targeting $\mathrm{SpO}_{2}$ of $85-89 \%$ or $90-94 \%$. Notably, the $95-99 \%$ target group showed a mean $\mathrm{FiO}_{2}$ of $50 \%$ and significantly higher pulmonary blood flow than the $100 \% \mathrm{FiO}_{2}$ group [94]. In addition, it is likely that the vasodilatory effect of hyperoxia is short-lived. In fetal lambs exposed to $100 \% \mathrm{FiO}_{2}$, hyperoxic pulmonary vasodilation peaked at approximately $50 \mathrm{~min}$ and decreased therafter [95]. Lastly, alveolar hyperoxia may increase pulmonary vascular contractility and impair responsiveness to pulmonary vasodilators, most notably inhaled nitric oxide, worsening outcomes in PPHN [96,97]. The optimal $\mathrm{SpO}_{2}$ in infants with PPHN remains unclear and requires further study.

\section{Future Directions}

\subsection{Limits of Pulse Oximetry}

All of the above studies rely on peripheral pulse oximetry measurements to guide supplemental oxygen administration. Refinements to oximeters and their software have improved portability and reliability; however, they continue to provide only a single data point (arterial oxygen saturation) to drive clinical decision making. The above studies were designed to optimize tissue oxygen delivery without exposing infants to excess oxygen; however, optimal oxgyen delivery depends on other factors, including hemoglobin concentration, tissue oxygen consumption, and hemodynamic status, among a multitude of others $[98,99]$.

In addition, preterm infants have predominantly fetal hemoglobin $(\mathrm{HbF})$, which binds more avidly to oxygen than the predominant adult form of hemoglobin $(\mathrm{HbA})$ [100]. The difference in relative oxygen affinity affects oxyhemoglobin dissociation and delivery to the tissues; thus, an infant with $95 \%$ oxyhemoglobin and predominantly $\mathrm{HbF}$ may deliver less oxygen to the tissues than an infant with $90 \%$ oxyhemoglobin and predominantly $\mathrm{HbA}$. While the ratio of $\mathrm{HbF}-\mathrm{to}-\mathrm{HbA}$ is highly associated with gestational age, interventions to improve oxygen delivery, such as blood transfusions (which are by necessity adult blood), can have a large impact on the amounts of each [101].

\subsection{Near-Infrared Spetroscopy}

One technology that provides data for other aspects of tissue oxygen delivery is near-infrared spectroscopy (NIRS). As with pulse oximetry, NIRS calculates the ratio of oxyhemoglobin to deoxyhemoglobin, but it does not identify the pulse waveform; therefore, it includes non-arterial sources of transmitted light from the monitored region [102,103]. Because they are measurements of regional oxygen saturation, NIRS measurements are affected by both oxygen consumption and oxygen delivery. The relative contributions of arterial (oxygen delivery) and venous (oxygen consumption) oxygen saturations are 
$30 \%$ and $70 \%$, respectively $[104,105]$. Cerebral regional oxygen saturation $\left(\mathrm{CrSO}_{2}\right)$ values have been found to be closely correlated with central venous oxygen saturation, a measure commonly used to calculate global oxygen consumption [106]. There are no established standards for use in neonates; however, multiple prior and ongoing research projects have investigated its use in monitoring regional oxygen saturation, most commonly in the brain and kidneys, and have proposed possible uses for these data [106-110].

A pilot study of very preterm ( $<32$ week) infants using the combination of peripheral pulse oximetry and $\mathrm{CrSO}_{2}$ found significant differences in combined values between infants who developed IVH between 12 and $72 \mathrm{~h}$ of life and those who did not [111]. Another study looking specifically at the newborn transition period (first $15 \mathrm{~min}$ of life) in very preterm infants found significantly lower $\mathrm{CrSO}_{2}$ in infants who went on to develop IVH in the first 14 days of life [112]. A European unblinded, randomized, controlled trial using $\mathrm{CrSO}_{2}$ to guide therapy, entitled Safeguarding the Brain of Our Smallest Children (SafeBoosC), set a target range for $\mathrm{CrSO}_{2}$ of $55 \%$ to $85 \%$ and provided 8 treatment options when $\mathrm{CrSO}_{2}$ went below 55\%. Notably, only one option involved increasing $\mathrm{FiO}_{2}$ [113]. The trial found a decrease in cerebral hypoxia $\left(\mathrm{CrSO}_{2}<55 \%\right)$ but no differences in rates of brain injury or neurodevelopmental outcomes at 2 years of age [114]. A systematic review of $\mathrm{CrSO}_{2}$-guided therapy trials found only one trial that met the quality parameters set by reviewers and did not show a reduction in brain injury with the use of cerebral NIRS monitoring [115].

Renal regional oxygen saturation $\left(\mathrm{RrSO}_{2}\right)$ may also provide enhanced data to guide therapy. It is possible that $\mathrm{RrSO}_{2}$ changes more rapidly than $\mathrm{CrSO}_{2}$ in response to discrepant oxygen delivery and oxygen consumption, as cerebral autoregulation protects the brain against rapid changes in perfusion in response to changes in hemodynamics [116]. Interestingly, higher $\mathrm{RrSO}_{2}$ in neonates with hypoxic ischemic encephalopathy was shown to be associated with acute kidney injury [117]. In contrast, in infants undergoing heart surgery, low $\mathrm{RrSO}_{2}$ was associated with the development of acute kidney injury [118].

Specific guidelines for the use and interpretation of NIRS may provide a framework to apply this technology to specific clinical scenarios to optimize oxygen delivery in the NICU [119]. The simplicity of pulse oximetry makes it an ideal monitor to guide clinical therapy, and the refinement of oxygen therapy guidelines using pulse oximetry has clearly shown benefit. The question remains whether the precision afforded by the addition of NIRS monitoring has enough benefit to overcome the burden of additional monitors on fragile infants in the NICU with limited body surface area.

\subsection{Novel Therapies}

In addition to limitations in monitoring, there are no available therapies to mitigate the effects of oxidative injury in the NICU. In a review of antioxidant therapies with particular focus on BPD, Ofman and Tipple outlined major barriers to effective therapies, including lack of compartment and target specificity, limited bioavailability, timing of therapy, and genetic variability [120]. Endogenous antioxidant enzymes are highly localized and perform specific functions in redox biochemistry. Systemic or even organ-specific administration of antioxidants may not reach the cells or organelles where hyperoxia induces injury. In addition, individual organs have variable oxygen consumption rates and respond differently to hypoxia and hyperoxia. This is evident in the NeOProM trials, where lower $\mathrm{SpO}_{2}$ targets were associated with NEC and mortality, while higher $\mathrm{SpO}_{2}$ targets were associated with ROP. Future therapies could target oxygen delivery specifically to the organs most in need. For example, a bio-engineered heme-containing protein, $\mathrm{OMX}-\mathrm{CV}$, has a 10 -fold higher affinity for oxygen than hemoglobin does and has been shown to selectively deliver oxygen to hypoxic tissues but not to tissues at physiologic oxygen tension rates in juvenile lambs [121].

Investigations of the redox signaling pathways involved in oxidative stress have revealed other potential future targets for clinical study. Thioredoxin is an antioxidant enzyme that catalyzes the reduction of oxidized cysteine residues, playing an important 
role in reducing protein disulfide bonds. Alterations in thioredoxin and its partner enzyme, thioredoxin reductase, have been shown to affect susceptibility to hyperoxic lung injury [122]. Interestingly, the drugs auranofin and aurothioglucose inhibit thioredoxin reductase and have been shown to protect mice from hyperoxic lung injury through the induction of nuclear factor erythroid 2-related factor (NRF2)-induced genes [123,124]. NRF2 is an oxidant-activated transcription factor that stimulates the transcription of a variety of endogenous antioxidant systems [125]. Similarly, melatonin is a neurohormone that induces a variety of endogenous antioxidant enzymes and has been shown to mitigate hyperoxic lung injury in rats, as well as hypoxic ischemic encephalopathy in pigs [126-128]. In contrast to trials involving the direct application of antioxidant enzymes or cofactors, these medications provide an alternative approach through the induction of endogenous antioxidant systems.

Lastly, patient responses to hypoxia and hyperoxia may vary based on genetic differences between antioxidant systems. In a population of very low birth weight infants, sequencing of a variety of antioxidant genes revealed single-nucleotide polymorphisms in the NQO1 gene (coding for NADPH quinone reductase) and the NFE2L2 gene (coding for NRF2), which were associated significant differences in the risk of BPD [129]. As exome and genome sequencing become cheaper and more ubiquitous in the NICU, identification of genetic differences in endogenous antioxidant genes may allow for individualized approaches to mitigating oxidative injury.

\section{Conclusions}

Preterm and term newborns are unique populations with decreased antioxidant capacity and dependence on redox signaling for rapid growth and development. Despite advances in neonatal care, supplemental oxygen remains the most commonly used drug in the NICU. While oxygen can be life-saving, it is toxic in excess. Its application to neonatal medicine has seen a dramatic pendulum swing, from ubiquitous use both in the delivery room and beyond to intense restriction due to concern for retinal disease. The introduction of the pulse oximeter to initial newborn resuscitation and the NICU allowed for targeted oxygen therapy, while broad international collaboration has resulted in ample data to support current guidelines. Nonetheless, pulse oximetry provides limited information with which to make therapeutic decisions, and supplemental oxygen remains a blunt and untargeted therapy. Future strategies to optimize oxygen delivery while mitigating oxidative damage may involve NIRS monitoring or organ-, cell-, and patient-specific therapies that harness endogenous antioxidant systems.

Author Contributions: M.M., J.C., M.P. and O.S. conceptualized the content and wrote, edited, and approved the manuscript. All authors have read and agreed to the published version of the manuscript.

Funding: This research was funded by the National Institutes of Health to J.C. (K08 HD102023) and M.P. (K08 HL124295).

Institutional Review Board Statement: Not applicable.

Informed Consent Statement: Not applicable.

Data Availability Statement: Not applicable.

Conflicts of Interest: The authors declare no conflict of interest.

\section{References}

1. Johnson, N.; Johnson, V.A.; McNamara, H.; Montague, I.A.; Jongsma, H.W.; Aumeerally, Z.; Gupta, J.K.; van Oudgaarden, E.; Lilford, R.J.; Miller, D. Fetal Pulse Oximetry: A New Method of Monitoring the Fetus. Aust. N. Z. J. Obstet. Gynaecol. 1994, 34, 428-432. [CrossRef]

2. Butte, N.F.; Moon, J.K.; Wong, W.W.; Hopkinson, J.M.; Smith, E.O. Energy Requirements from Infancy to Adulthood. Am. J. Clin. Nutr. 1995, 62, 1047S-1052S. [CrossRef] 
3. Vannucci, S.J. Developmental Expression of GLUT1 and GLUT3 Glucose Transporters in Rat Brain. J. Neurochem. 1994, 62, 240-246. [CrossRef]

4. Ten, V.S.; Stepanova, A.A.; Ratner, V.; Neginskaya, M.; Niatsetskaya, Z.; Sosunov, S.; Starkov, A. Mitochondrial Dysfunction and Permeability Transition in Neonatal Brain and Lung Injuries. Cells 2021, 10, 569. [CrossRef]

5. Finkel, T. Signal Transduction by Mitochondrial Oxidants. J. Biol. Chem. 2012, 287, 4434-4440. [CrossRef] [PubMed]

6. Berkelhamer, S.K.; Kim, G.A.; Radder, J.E.; Wedgwood, S.; Czech, L.; Steinhorn, R.H.; Schumacker, P.T. Developmental Differences in Hyperoxia-Induced Oxidative Stress and Cellular Responses in the Murine Lung. Free Radic. Biol. Med. 2013, 61, 51-60. [CrossRef] [PubMed]

7. Saugstad, O.D.; Hallman, M.; Abraham, J.L.; Epstein, B.; Cochrane, C.; Gluck, L. Hypoxanthine and Oxygen Induced Lung Injury: A Possible Basic Mechanism of Tissue Damage? Pediatr. Res. 1984, 18, 501-504. [CrossRef]

8. Ogihara, T.; Hirano, K.; Morinobu, T.; Kim, H.-S.; Hiroi, M.; Ogihara, H.; Tamai, H. Raised Concentrations of Aldehyde Lipid Peroxidation Products in Premature Infants with Chronic Lung Disease. Arch. Dis. Child. Fetal Neonatal. Ed. 1999, 80, F21-F25. [CrossRef]

9. Warner, B.B.; Stuart, L.A.; Papes, R.A.; Wispé, J.R. Functional and Pathological Effects of Prolonged Hyperoxia in Neonatal Mice. Am. J. Physiol. -Lung Cell. Mol. Physiol. 1998, 275, L110-L117. [CrossRef] [PubMed]

10. Ratner, V.; Starkov, A.; Matsiukevich, D.; Polin, R.A.; Ten, V.S. Mitochondrial Dysfunction Contributes to Alveolar Developmental Arrest in Hyperoxia-Exposed Mice. Am. J. Respir. Cell Mol. Biol. 2009, 40, 511-518. [CrossRef]

11. Giannone, P.; Bauer, J.; Schanbacher, B.; Reber, K. Effects of Hyperoxia on Postnatal Intestinal Development. Biotech. Histochem. 2007, 82, 17-22. [CrossRef]

12. Liu, D.Y.; Lou, W.J.; Zhang, D.Y.; Sun, S.Y. ROS Plays a Role in the Neonatal Rat Intestinal Barrier Damages Induced by Hyperoxia. BioMed Res. Int. 2020, 2020, e8819195. [CrossRef]

13. Hartnett, M.E.; Penn, J.S. Mechanisms and Management of Retinopathy of Prematurity. N. Engl. J. Med. 2012, 367, 2515-2526. [CrossRef]

14. Kennedy, C.; Grave, G.D.; Sokoloff, L. Alterations of Local Cerebral Blood Flow Due to Exposure of Newborn Puppies to 80-90 per Cent Oxygen. Eur. Neurol. 1971, 6, 137-140. [CrossRef] [PubMed]

15. Liu, Y.; Jiang, P.; Du, M.; Chen, K.; Chen, A.; Wang, Y.; Cao, F.; Deng, S.; Xu, Y. Hyperoxia-Induced Immature Brain Injury through the TLR4 Signaling Pathway in Newborn Mice. Brain Res. 2015, 1610, 51-60. [CrossRef]

16. Du, M.; Tan, Y.; Liu, G.; Liu, L.; Cao, F.; Liu, J.; Jiang, P.; Xu, Y. Effects of the Notch Signalling Pathway on Hyperoxia-Induced Immature Brain Damage in Newborn Mice. Neurosci. Lett. 2017, 653, 220-227. [CrossRef]

17. Lee, Y.-S.; Chou, Y.-H. Antioxidant Profiles in Full Term and Preterm Neonates. Chang. Gung Med. J. 2005, 28, 846-851. [PubMed]

18. Heinonen, K.; Mononen, I.; Mononen, T.; Parviainen, M.; Penttilä, I.; Launiala, K. Plasma Vitamin C Levels Are Low in Premature Infants Fed Human Milk. Am. J. Clin. Nutr 1986, 43, 923-924. [CrossRef] [PubMed]

19. Fort, P.; Salas, A.A.; Nicola, T.; Craig, C.M.; Carlo, W.A.; Ambalavanan, N. A Comparison of 3 Vitamin D Dosing Regimens in Extremely Preterm Infants: A Randomized Controlled Trial. J. Pediatr. 2016, 174, 132-138.e1. [CrossRef]

20. Falciglia, H.S.; Ginn-Pease, M.E.; Falciglia, G.A.; Lubin, A.H.; Frank, D.J.; Chang, W. Vitamin E and Selenium Levels of Premature Infants with Severe Respiratory Distress Syndrome and Bronchopulmonary Dysplasia. J. Pediatr. Perinat Nutr. 1988, 2, 35-49. [CrossRef]

21. Rosenfeld, W.; Evans, H.; Concepcion, L.; Jhaveri, R.; Schaeffer, H.; Friedman, A. Prevention of Bronchopulmonary Dysplasia by Administration of Bovine Superoxide Dismutase in Preterm Infants with Respiratory Distress Syndrome. J. Pediatr. 1984, 105, 781-785. [CrossRef]

22. Davis, J.M.; Rosenfeld, W.N.; Richter, S.E.; Parad, R.; Gewolb, I.H.; Spitzer, A.R.; Carlo, W.A.; Couser, R.J.; Price, A.; Flaster, E.; et al. Safety and Pharmacokinetics of Multiple Doses of Recombinant Human CuZn Superoxide Dismutase Administered Intratracheally to Premature Neonates with Respiratory Distress Syndrome. Pediatrics 1997, 100, 24-30. [CrossRef]

23. Davis, J.M.; Parad, R.B.; Michele, T.; Allred, E.; Price, A.; Rosenfeld, W. Pulmonary Outcome at 1 Year Corrected Age in Premature Infants Treated at Birth with Recombinant Human CuZn Superoxide Dismutase. Pediatrics 2003, 111, 469-476. [CrossRef]

24. Suresh, G.; Davis, J.M.; Soll, R. Superoxide Dismutase for Preventing Chronic Lung Disease in Mechanically Ventilated Preterm Infants. Cochrane Database Syst. Rev. 2001, 2001, CD001968. [CrossRef] [PubMed]

25. Meyer, S.; Gortner, L.; Investigators, N.T. Early Postnatal Additional High-Dose Oral Vitamin A Supplementation versus Placebo for 28 Days for Preventing Bronchopulmonary Dysplasia or Death in Extremely Low Birth Weight Infants. Neonatology 2014, 105, 182-188. [CrossRef] [PubMed]

26. Meyer, S.; Gortner, L.; Meyer, S.; Bay, J.; Gortner, L.; Ehrlich, A.; Ruckes, C.; Seidenberg, J.; Muyimbwa, J.; Wieg, C.; et al. Up-Date on the NeoVitaA Trial: Obstacles, Challenges, Perspectives, and Local Experiences. Wien. Med. Wochenschr. 2017, 167, 264-270. [CrossRef] [PubMed]

27. Tyson, J.E.; Kennedy, K.A.; Stoll, B.J.; Bauer, C.R. Vitamin A Supplementation for Extremely-Low-Birth-Weight Infants. N. Engl. J. Med. 1999, 7. [CrossRef]

28. Darlow, B.A.; Graham, P.J.; Rojas-Reyes, M.X. Vitamin A Supplementation to Prevent Mortality and Short- and Long-term Morbidity in Very Low Birth Weight Infants. Cochrane Database Syst. Rev. 2016, 2016, CD000501. [CrossRef] 
29. Kiatchoosakun, P.; Jirapradittha, J.; Panthongviriyakul, M.C.; Khampitak, T.; Yongvanit, P.; Boonsiri, P. Vitamin A Supplementation for Prevention of Bronchopulmonary Dysplasia in Very-Low-Birth-Weight Premature Thai Infants: A Randomized Trial. J. Med. Assoc. Thai 2014, 97 (Suppl. S10), S82-S88.

30. Darlow, B.A.; Buss, H.; McGill, F.; Fletcher, L.; Graham, P.; Winterbourn, C.C. Vitamin C Supplementation in Very Preterm Infants: A Randomised Controlled Trial. Arch. Dis Child. Fetal Neonatal Ed. 2005, 90, F117-F122. [CrossRef]

31. Brion, L.P.; Bell, E.F.; Raghuveer, T.S. Vitamin E Supplementation for Prevention of Morbidity and Mortality in Preterm Infants. Cochrane Database Syst. Rev. 2003, 2003, CD003665. [CrossRef]

32. Stone, C.A., Jr.; McEvoy, C.T.; Aschner, J.L.; Kirk, A.; Rosas-Salazar, C.; Cook-Mills, J.M.; Moore, P.E.; Walsh, W.F.; Hartert, T.V. Update on Vitamin E and Its Potential Role in Preventing or Treating Bronchopulmonary Dysplasia. Neonatology 2018, 113, 366-378. [CrossRef] [PubMed]

33. Watts, J.L.; Milner, R.; Zipursky, A.; Paes, B.; Ling, E.; Gill, G.; Fletcher, B.; Rand, C. Failure of Supplementation with Vitamin E to Prevent Bronchopulmonary Dysplasia in Infants Less than $1500 \mathrm{~g}$ Birth Weight. Eur. Respir. J. 1991, 4, 188-190. [PubMed]

34. Ahola, T.; Lapatto, R.; Raivio, K.O.; Selander, B.; Stigson, L.; Jonsson, B.; Jonsbo, F.; Esberg, G.; Stövring, S.; Kjartansson, S.; et al. N-Acetylcysteine Does Not Prevent Bronchopulmonary Dysplasia in Immature Infants: A Randomized Controlled Trial. J. Pediatr. 2003, 143, 713-719. [CrossRef]

35. Rhee, S.G.; Bae, Y.S.; Lee, S.-R.; Kwon, J. Hydrogen Peroxide: A Key Messenger That Modulates Protein Phosphorylation Through Cysteine Oxidation. Sci. Signal. 2000, 2000, pe1. [CrossRef] [PubMed]

36. Salmeen, A.; Andersen, J.N.; Myers, M.P.; Meng, T.-C.; Hinks, J.A.; Tonks, N.K.; Barford, D. Redox Regulation of Protein Tyrosine Phosphatase 1B Involves a Sulphenyl-Amide Intermediate. Nature 2003, 423, 769-773. [CrossRef]

37. Lee, S.-R.; Kwon, K.-S.; Kim, S.-R.; Rhee, S.G. Reversible Inactivation of Protein-Tyrosine Phosphatase 1B in A431 Cells Stimulated with Epidermal Growth Factor*. J. Biol. Chem. 1998, 273, 15366-15372. [CrossRef]

38. Oshikawa, J.; Urao, N.; Kim, H.W.; Kaplan, N.; Razvi, M.; McKinney, R.; Poole, L.B.; Fukai, T.; Ushio-Fukai, M. Extracellular SOD-Derived $\mathrm{H}_{2} \mathrm{O}_{2}$ Promotes VEGF Signaling in Caveolae/Lipid Rafts and Post-Ischemic Angiogenesis in Mice. PLoS ONE 2010, 5, e10189. [CrossRef]

39. Nezu, M.; Souma, T.; Yu, L.; Sekine, H.; Takahashi, N.; Wei, A.Z.-S.; Ito, S.; Fukamizu, A.; Zsengeller, Z.K.; Nakamura, T.; et al. Nrf2 Inactivation Enhances Placental Angiogenesis in a Preeclampsia Mouse Model and Improves Maternal and Fetal Outcomes. Sci. Signal. 2017, 10, eaam5711. [CrossRef]

40. Flagg, P.J. Treatment of Asphyxia in the New-Born: Preliminary Report of the Practical Application of Modern Scientific Methods. J. Am. Med. Assoc. 1928, 91, 788-791. [CrossRef]

41. Terry, T.L. Extreme Prematurity and Fibroblastic Overgrowth of Persistent Vascular Sheath Behind Each Crystalline Lens: I. Preliminary Report. Am. J. Ophthalmol. 2018, 192, xxviii. [CrossRef]

42. Owens, W.C.; Owens, E.U. Retrolental Fibroplasia in Premature Infants. Trans. Am. Acad. Ophthalmol. Otolaryngol. 1948, 53, 18-41.

43. Appelbaum, A. Retrolental Fibroplasia-Blindness in Infants of Low Weight at Birth. Calif. Med. 1952, 77, $259-265$.

44. Kinsey, V.E. Retrolental Fibroplasia; Cooperative Study of Retrolental Fibroplasia and the Use of Oxygen. AMA Arch. Ophthalmol. 1956, 56, 481-543. [CrossRef]

45. Campbell, K. Intensive Oxygen Therapy as a Possible Cause of Retrolental Fibroplasia; a Clinical Approach. Med. J. Aust. 1951, 2, 48-50. [CrossRef]

46. Cross, K.W. Cost of preventing retrolental fibroplasia? Lancet 1973, 302, 954-956. [CrossRef]

47. Lucey, J.F.; Dangman, B. A Reexamination of the Role of Oxygen in Retrolental Fibroplasia. Pediatrics 1984, 73, 82-96.

48. Klaus, M.; Meyer, B.P. Oxygen Therapy for the Newborn. Pediatr. Clin. N. Am. 1966, 13, 731-752. [CrossRef]

49. Kerber, R.; Ornato, J.; Brown, D.; Chameides, L.; Chandra, N.; Cummins, R.; Hazinski, M.; Melker, R.; Weaver, D. Emergency Cardiac Care Committee and Subcommittees, American Heart Association. JAMA 1992, 268, 2171. [CrossRef]

50. Saugstad, O.D.; Gluck, L. Plasma Hypoxanthine Levels in Newborn Infants: A Specific Indicator of Hypoxia. J. Perinat Med. 1982, 10, 266-272. [CrossRef] [PubMed]

51. Feet, B.A.; Yu, X.-Q.; Rootwelt, T.; Oyasaeter, S.; Saugstad, O.D. Effects of Hypoxemia and Reoxygenation with $21 \%$ or $100 \%$ Oxygen in Newborn Piglets: Extracellular Hypoxanthine in Cerebral Cortex and Femoral Muscle. Crit. Care Med. 1997, 25, 1384-1391. [CrossRef]

52. Rootwelt, T.; Løberg, E.M.; Moen, A.; Øyasæter, S.; Saugstad, O.D. Hypoxemia and Reoxygenation with $21 \%$ or $100 \%$ Oxygen in Newborn Pigs: Changes in Blood Pressure, Base Deficit, and Hypoxanthine and Brain Morphology. Pediatr. Res. 1992, 32, 107-113. [CrossRef] [PubMed]

53. Saugstad, O.D.; Rootwelt, T.; Aalen, O. Resuscitation of Asphyxiated Newborn Infants with Room Air or Oxygen: An International Controlled Trial: The Resair 2 Study. Pediatrics 1998, 102, e1. [CrossRef] [PubMed]

54. Saugstad, O.D.; Ramji, S.; Irani, S.F.; El-Meneza, S.; Hernandez, E.A.; Vento, M.; Talvik, T.; Solberg, R.; Rootwelt, T.; Aalen, O.O. Resuscitation of Newborn Infants with $21 \%$ or $100 \%$ Oxygen: Follow-Up at 18 to 24 Months. Pediatrics 2003, 112, 296-300. [CrossRef]

55. Vento, M.; Asensi, M.; Sastre, J.; Garciía-Sala, F.; Pallardó, F.V.; Viña, J. Resuscitation with Room Air Instead of 100\% Oxygen Prevents Oxidative Stress in Moderately Asphyxiated Term Neonates. Pediatrics 2001, 107, 642-647. [CrossRef] [PubMed]

56. Vento, M.; Asensi, M.; Sastre, J.; García-Sala, F.; Viña, J. Six Years of Experience with the Use of Room Air for the Resuscitation of Asphyxiated Newly Born Term Infants. Biol. Neonate 2001, 79, 261-267. [CrossRef] 
57. Welsford, M.; Nishiyama, C.; Shortt, C.; Isayama, T.; Dawson, J.A.; Weiner, G.; Roehr, C.C.; Wyckoff, M.H.; Rabi, Y. Room Air for Initiating Term Newborn Resuscitation: A Systematic Review with Meta-Analysis. Pediatrics 2019, 143, e20181825. [CrossRef]

58. Escobedo, M.B.; Aziz, K.; Kapadia, V.S.; Lee, H.C.; Niermeyer, S.; Schmölzer, G.M.; Szyld, E.; Weiner, G.M.; Wyckoff, M.H.; Yamada, N.K.; et al. 2019 American Heart Association Focused Update on Neonatal Resuscitation: An Update to the American Heart Association Guidelines for Cardiopulmonary Resuscitation and Emergency Cardiovascular Care. Pediatrics 2020, 145, e922-e930. [CrossRef]

59. Wyckoff, M.H.; Wyllie, J.; Aziz, K.; de Almeida, M.F.; Fabres, J.; Fawke, J.; Guinsburg, R.; Hosono, S.; Isayama, T.; Kapadia, V.S.; et al. Neonatal Life Support: 2020 International Consensus on Cardiopulmonary Resuscitation and Emergency Cardiovascular Care Science with Treatment Recommendations. Circulation 2020, 142, S185-S221. [CrossRef]

60. Lui, K.; Jones, L.J.; Foster, J.P.; Davis, P.G.; Ching, S.K.; Oei, J.L.; Osborn, D.A. Lower versus Higher Oxygen Concentrations Titrated to Target Oxygen Saturations during Resuscitation of Preterm Infants at Birth. Cochrane Database Syst. Rev. 2018, 2018, CD010239. [CrossRef]

61. Oei, J.L.; Saugstad, O.D.; Lui, K.; Wright, I.M.; Smyth, J.P.; Craven, P.; Wang, Y.A.; McMullan, R.; Coates, E.; Ward, M.; et al. Targeted Oxygen in the Resuscitation of Preterm Infants, a Randomized Clinical Trial. Pediatrics 2017, 139. [CrossRef] [PubMed]

62. Rabi, Y.; Lodha, A.; Soraisham, A.; Singhal, N.; Barrington, K.; Shah, P.S. Outcomes of Preterm Infants Following the Introduction of Room Air Resuscitation. Resuscitation 2015, 96, 252-259. [CrossRef] [PubMed]

63. Soraisham, A.S.; Rabi, Y.; Shah, P.S.; Singhal, N.; Synnes, A.; Yang, J.; Lee, S.K.; Lodha, A.K. Neurodevelopmental Outcomes of Preterm Infants Resuscitated with Different Oxygen Concentration at Birth. J. Perinatol. 2017, 37, 1141-1147. [CrossRef] [PubMed]

64. Thamrin, V.; Saugstad, O.D.; Tarnow-Mordi, W.; Wang, Y.A.; Lui, K.; Wright, I.M.; De Waal, K.; Travadi, J.; Smyth, J.P.; Craven, P.; et al. Preterm Infant Outcomes after Randomization to Initial Resuscitation with $\mathrm{FiO}_{2}$ 0.21 or 1.0. J. Pediatr. 2018, 201, 55-61.e1. [CrossRef]

65. Kapadia, V.; Oei, J.L.; Finer, N.; Rich, W.; Rabi, Y.; Wright, I.M.; Rook, D.; Vermeulen, M.J.; Tarnow-Mordi, W.O.; Smyth, J.P.; et al. Outcomes of Delivery Room Resuscitation of Bradycardic Preterm Infants: A Retrospective Cohort Study of Randomised Trials of High vs. Low Initial Oxygen Concentration and an Individual Patient Data Analysis. Resuscitation 2021, 167, 209-217. [CrossRef]

66. Greenspan, J.S.; Goldsmith, J.P. Oxygen Therapy in Preterm Infants: Hitting the Target. Pediatrics 2006, 118, 1740-1741. [CrossRef]

67. Silverman, W.A. Oxygen Therapy and Retrolental Fibroplasia. Am. J. Public Health Nations Health 1968, 58, 2009-2011. [CrossRef]

68. Askie, L.M.; Henderson-Smart, D.J.; Ko, H. Restricted versus Liberal Oxygen Exposure for Preventing Morbidity and Mortality in Preterm or Low Birth Weight Infants. Cochrane Database Syst. Rev. 2009, 2009, CD001077. [CrossRef]

69. Askie, L.M.; Darlow, B.A.; Finer, N.; Schmidt, B.; Stenson, B.; Tarnow-Mordi, W.; Davis, P.G.; Carlo, W.A.; Brocklehurst, P.; Davies, L.C.; et al. Association Between Oxygen Saturation Targeting and Death or Disability in Extremely Preterm Infants in the Neonatal Oxygenation Prospective Meta-Analysis Collaboration. JAMA 2018, 319, 2190-2201. [CrossRef]

70. Robertson, A.F. Reflections on Errors in Neonatology: I. The "Hands-Off" Years, 1920 to 1950. J. Perinatol. 2003, $23,48-55$. [CrossRef]

71. Saugstad, O.D. Oxygenation of the Immature Infant: A Commentary and Recommendations for Oxygen Saturation Targets and Alarm Limits. Neonatology 2018, 114, 69-75. [CrossRef] [PubMed]

72. Lanman, J.T.; Guy, L.P.; Dancis, J. Retrolental Fibroplasia and Oxygen Therapy. J. Am. Med. Assoc. 1954, 155, 223-226. [CrossRef]

73. Patz, A. Oxygen Studies in Retrolental Fibroplasia*: IV. Clinical and Experimental Observations the First Edward L. Holmes Memorial Lecture. Am. J. Ophthalmol. 1954, 38, 291-308. [CrossRef]

74. Patz, A. The Role of Oxygen in Retrolental Fibroplasia. Sinai Hosp. J. 1954, 3, 6-20. [CrossRef] [PubMed]

75. STOP-ROP Multicenter Study Group. Supplemental Therapeutic Oxygen for Prethreshold Retinopathy of Prematurity (STOPROP), A Randomized, Controlled Trial. I: Primary Outcomes. Pediatrics 2000, 105, 295-310. [CrossRef] [PubMed]

76. SUPPORT Study Group of the Eunice Kennedy Shriver NICHD Neonatal Research Network; Carlo, W.A.; Finer, N.N.; Walsh, M.C.; Rich, W.; Gantz, M.G.; Laptook, A.R.; Yoder, B.A.; Faix, R.G.; Das, A.; et al. Target Ranges of Oxygen Saturation in Extremely Preterm Infants. N. Engl. J. Med. 2010, 362, 1959-1969. [CrossRef] [PubMed]

77. BOOST II United Kingdom Collaborative Group; BOOST II Australia Collaborative Group; BOOST II New Zealand Collaborative Group; Stenson, B.J.; Tarnow-Mordi, W.O.; Darlow, B.A.; Simes, J.; Juszczak, E.; Askie, L.; Battin, M.; et al. Oxygen Saturation and Outcomes in Preterm Infants. N. Engl. J. Med. 2013, 368, 2094-2104. [CrossRef]

78. Stenson, B.; Brocklehurst, P.; Tarnow-Mordi, W. Increased 36-Week Survival with High Oxygen Saturation Target in Extremely Preterm Infants. N. Engl. J. Med. 2011, 364, 1680-1682. [CrossRef] [PubMed]

79. BOOST-II Australia and United Kingdom Collaborative Groups; Tarnow-Mordi, W.; Stenson, B.; Kirby, A.; Juszczak, E.; Donoghoe, M.; Deshpande, S.; Morley, C.; King, A.; Doyle, L.W.; et al. Outcomes of Two Trials of Oxygen-Saturation Targets in Preterm Infants. N. Engl. J. Med. 2016, 374, 749-760. [CrossRef]

80. Al Hazzani, F.; Khadawardi, E. Effects of Targeting Higher vs. Lower Arterial Oxygen Saturations on Death or Disability in Extremely Preterm Infants: The Canadian Oxygen Trial. J. Clin. Neonatol. 2013, 2, 70-72. [CrossRef]

81. Saugstad, O.D.; Aune, D. Optimal Oxygenation of Extremely Low Birth Weight Infants: A Meta-Analysis and Systematic Review of the Oxygen Saturation Target Studies. Neonatology 2014, 105, 55-63. [CrossRef] [PubMed]

82. Manja, V.; Lakshminrusimha, S.; Cook, D.J. Oxygen Saturation Target Range for Extremely Preterm Infants: A Systematic Review and Meta-Analysis. JAMA Pediatr. 2015, 169, 332-340. [CrossRef] [PubMed] 
83. Manja, V.; Saugstad, O.D.; Lakshminrusimha, S. Oxygen Saturation Targets in Preterm Infants and Outcomes at 18-24 Months: A Systematic Review. Pediatrics 2017, 139, e20161609. [CrossRef] [PubMed]

84. Schmidt, B.; Whyte, R.K. Oxygen Saturation Target Ranges and Alarm Settings in the NICU: What Have We Learnt from the Neonatal Oxygenation Prospective Meta-Analysis (NeOProM)? Semin. Fetal. Neonatal Med. 2020, 25, 101080. [CrossRef] [PubMed]

85. Askie, L.M. Meta-Analysis of Oxygenation Saturation Targeting Trials: Do Infant Subgroups Matter? Clin. Perinatol. 2019, 46, 579-591. [CrossRef]

86. Kilpatrick, S.J.; American Academy of Pediatrics; American College of Obstetricians and Gynecologists. Guidelines for Perinatal Care; American Academy of Pediatrics; The American College of Obstetricians and Gynecologists: Washington, DC, USA, 2017; ISBN 978-1-61002-088-6.

87. Sweet, D.G.; Carnielli, V.; Greisen, G.; Hallman, M.; Ozek, E.; Te Pas, A.; Plavka, R.; Roehr, C.C.; Saugstad, O.D.; Simeoni, U.; et al. European Consensus Guidelines on the Management of Respiratory Distress Syndrome-2019 Update. Neonatology 2019, 115, 432-450. [CrossRef]

88. Bashinsky, A.L. Retinopathy of Prematurity. North. Carol. Med. J. 2017, 78, 124-128. [CrossRef]

89. Hartnett, M.E.; Lane, R.H. Effects of Oxygen on the Development and Severity of Retinopathy of Prematurity. J. Am. Assoc. Pediatr. Ophthalmol. Strabismus 2013, 17, 229-234. [CrossRef]

90. Shukla, A.; Sonnie, C.; Worley, S.; Sharma, A.; Howard, D.; Moore, J.; Rodriguez, R.J.; Hoppe, G.; Sears, J.E. Comparison of Biphasic vs. Static Oxygen Saturation Targets Among Infants with Retinopathy of Prematurity. JAMA Ophthalmol. 2019, 137, 417-423. [CrossRef]

91. Sharma, M.; Mohan, K.R.; Narayan, S.; Chauhan, L. Persistent Pulmonary Hypertension of the Newborn: A Review. Med. J. Armed Forces India 2011, 67, 348-353. [CrossRef]

92. Rudolph, A.M.; Yuan, S. Response of the Pulmonary Vasculature to Hypoxia and H+ Ion Concentration Changes. J. Clin. Investig. 1966, 45, 399-411. [CrossRef] [PubMed]

93. Nair, J.; Lakshminrusimha, S. Update on pphn: Mechanisms and treatment. Semin. Perinatol. 2014, 38, 78-91. [CrossRef] [PubMed]

94. Rawat, M.; Chandrasekharan, P.; Gugino, S.F.; Koenigsknecht, C.; Nielsen, L.; Wedgwood, S.; Mathew, B.; Nair, J.; Steinhorn, R.; Lakshminrusimha, S. Optimal Oxygen Targets in Term Lambs with Meconium Aspiration Syndrome and Pulmonary Hypertension. Am. J. Respir Cell Mol. Biol 2020, 63, 510-518. [CrossRef] [PubMed]

95. Accurso, F.J.; Alpert, B.; Wilkening, R.B.; Petersen, R.G.; Meschia, G. Time-Dependent Response of Fetal Pulmonary Blood Flow to an Increase in Fetal Oxygen Tension. Respir. Physiol. 1986, 63, 43-52. [CrossRef]

96. Lakshminrusimha, S.; Russell, J.A.; Steinhorn, R.H.; Ryan, R.M.; Gugino, S.F.; Morin, F.C.; Swartz, D.D.; Kumar, V.H. Pulmonary Arterial Contractility in Neonatal Lambs Increases with 100\% Oxygen Resuscitation. Pediatr. Res. 2006, 59, 137-141. [CrossRef]

97. Lakshminrusimha, S.; Swartz, D.D.; Gugino, S.F.; Ma, C.-X.; Wynn, K.A.; Ryan, R.M.; Russell, J.A.; Steinhorn, R.H. Oxygen Concentration and Pulmonary Hemodynamics in Newborn Lambs with Pulmonary Hypertension. Pediatr. Res. 2009, 66, 539-544. [CrossRef]

98. Dunn, J.-O.; Mythen, M.; Grocott, M. Physiology of Oxygen Transport. BJA Educ. 2016, 16, 341-348. [CrossRef]

99. Whyte, R.K.; Jangaard, K.A.; Dooley, K.C. From Oxygen Content to Pulse Oximetry: Completing the Picture in the Newborn. Acta Anaesthesiol. Scand. Suppl. 1995, 107, 95-100. [CrossRef]

100. Wilson, K.; Hawken, S.; Murphy, M.S.Q.; Atkinson, K.M.; Potter, B.K.; Sprague, A.; Walker, M.; Chakraborty, P.; Little, J. Postnatal Prediction of Gestational Age Using Newborn Fetal Hemoglobin Levels. EBioMedicine 2017, 15, 203-209. [CrossRef]

101. De Halleux, V.; Truttmann, A.; Gagnon, C.; Bard, H. The Effect of Blood Transfusion on the Hemoglobin Oxygen Dissociation Curve of Very Early Preterm Infants during the First Week of Life. Semin. Perinatol. 2002, 26, 411-415. [CrossRef]

102. Whetsel, K.B. Near-Infrared Spectrophotometry. Appl. Spectrosc. Rev. 1968, 2, 1-67. [CrossRef]

103. Suzuki, S.; Takasaki, S.; Ozaki, T.; Kobayashi, Y. Tissue Oxygenation Monitor Using NIR Spatially Resolved Spectroscopy. In Proceedings of the Optical Tomography and Spectroscopy of Tissue III, San Jose, CA, USA, 24-28 January 1999; Volume 3597, pp. 582-592.

104. Watzman, H.M.; Kurth, C.D.; Montenegro, L.M.; Rome, J.; Steven, J.M.; Nicolson, S.C. Arterial and Venous Contributions to Near-Infrared Cerebral Oximetry. Anesthesiology 2000, 93, 947-953. [CrossRef] [PubMed]

105. Wong, F.Y.; Alexiou, T.; Samarasinghe, T.; Brodecky, V.; Walker, A.M. Cerebral Arterial and Venous Contributions to Tissue Oxygenation Index Measured Using Spatially Resolved Spectroscopy in Newborn Lambs. Anesthesiology 2010, 113, $1385-1391$. [CrossRef]

106. Weiss, M.; Dullenkopf, A.; Kolarova, A.; Schulz, G.; Frey, B.; Baenziger, O. Near-Infrared Spectroscopic Cerebral Oxygenation Reading in Neonates and Infants Is Associated with Central Venous Oxygen Saturation. Paediatr. Anaesth. 2005, 15, 102-109. [CrossRef] [PubMed]

107. Greisen, G.; Leung, T.; Wolf, M. Has the Time Come to Use Near-Infrared Spectroscopy as a Routine Clinical Tool in Preterm Infants Undergoing Intensive Care? Philos. Trans. A Math. Phys. Eng. Sci. 2011, 369, 4440-4451. [CrossRef]

108. van Bel, F.; Lemmers, P.; Naulaers, G. Monitoring Neonatal Regional Cerebral Oxygen Saturation in Clinical Practice: Value and Pitfalls. Neonatology 2008, 94, 237-244. [CrossRef]

109. Petrova, A.; Mehta, R. Near-Infrared Spectroscopy in the Detection of Regional Tissue Oxygenation during Hypoxic Events in Preterm Infants Undergoing Critical Care. Pediatr. Crit. Care Med. 2006, 7, 449. [CrossRef] 
110. Edwards, A.D.; Richardson, C.; Cope, M.; Wyatt, J.S.; Delpy, D.T.; Reynolds, E.O.R. Cotside measurement of cerebral blood flow in ill newborn infants by near infrared spectroscopy. Lancet 1988, 332, 770-771. [CrossRef]

111. Cimatti, A.G.; Martini, S.; Galletti, S.; Vitali, F.; Aceti, A.; Frabboni, G.; Faldella, G.; Corvaglia, L. Cerebral Oxygenation and Autoregulation in Very Preterm Infants Developing IVH During the Transitional Period: A Pilot Study. Front. Pediatr. 2020, 8, 381. [CrossRef] [PubMed]

112. Baik, N.; Urlesberger, B.; Schwaberger, B.; Schmölzer, G.M.; Avian, A.; Pichler, G. Cerebral Haemorrhage in Preterm Neonates: Does Cerebral Regional Oxygen Saturation during the Immediate Transition Matter? Arch. Dis. Child. Fetal. Neonatal. Ed. 2015, 100, F422-F427. [CrossRef]

113. Hyttel-Sorensen, S.; Pellicer, A.; Alderliesten, T.; Austin, T.; van Bel, F.; Benders, M.; Claris, O.; Dempsey, E.; Franz, A.R.; Fumagalli, M.; et al. Cerebral near Infrared Spectroscopy Oximetry in Extremely Preterm Infants: Phase II Randomised Clinical Trial. BMJ 2015, 350, g7635. [CrossRef] [PubMed]

114. Plomgaard, A.M.; Alderliesten, T.; van Bel, F.; Benders, M.; Claris, O.; Cordeiro, M.; Dempsey, E.; Fumagalli, M.; Gluud, C.; Hyttel-Sorensen, S.; et al. No Neurodevelopmental Benefit of Cerebral Oximetry in the First Randomised Trial (SafeBoosC II) in Preterm Infants during the First Days of Life. Acta Paediatr. 2019, 108, 275-281. [CrossRef] [PubMed]

115. Hyttel-Sorensen, S.; Greisen, G.; Als-Nielsen, B.; Gluud, C. Cerebral Near-Infrared Spectroscopy Monitoring for Prevention of Brain Injury in Very Preterm Infants. Cochrane Database Syst. Rev. 2017, 9, CD011506. [CrossRef]

116. Mintzer, J.P.; Moore, J.E. Regional Tissue Oxygenation Monitoring in the Neonatal Intensive Care Unit: Evidence for Clinical Strategies and Future Directions. Pediatr Res. 2019, 86, 296-304. [CrossRef] [PubMed]

117. Chock, V.Y.; Frymoyer, A.; Yeh, C.G.; Van Meurs, K.P. Renal Saturation and Acute Kidney Injury in Neonates with Hypoxic Ischemic Encephalopathy Undergoing Therapeutic Hypothermia. J. Pediatr. 2018, 200, 232-239.e1. [CrossRef]

118. Ruf, B.; Bonelli, V.; Balling, G.; Hörer, J.; Nagdyman, N.; Braun, S.L.; Ewert, P.; Reiter, K. Intraoperative Renal Near-Infrared Spectroscopy Indicates Developing Acute Kidney Injury in Infants Undergoing Cardiac Surgery with Cardiopulmonary Bypass: A Case-Control Study. Crit. Care 2015, 19, 27. [CrossRef]

119. Vesoulis, Z.A.; Mintzer, J.P.; Chock, V.Y. Neonatal NIRS Monitoring: Recommendations for Data Capture and Review of Analytics. J. Perinatol. 2021, 41, 675-688. [CrossRef] [PubMed]

120. Ofman, G.; Tipple, T.E. Antioxidants \& Bronchopulmonary Dysplasia: Beating the System or Beating a Dead Horse? Free Radic. Biol. Med. 2019, 142, 138-145. [CrossRef] [PubMed]

121. Boehme, J.; Le Moan, N.; Kameny, R.J.; Loucks, A.; Johengen, M.J.; Lesneski, A.L.; Gong, W.; Goudy, B.D.; Davis, T.; Tanaka, K.; et al. Preservation of Myocardial Contractility during Acute Hypoxia with OMX-CV, a Novel Oxygen Delivery Biotherapeutic. PLoS Biol. 2018, 16, e2005924. [CrossRef]

122. Tipple, T.E.; Welty, S.E.; Rogers, L.K.; Hansen, T.N.; Choi, Y.-E.; Kehrer, J.P.; Smith, C.V. Thioredoxin-Related Mechanisms in Hyperoxic Lung Injury in Mice. Am. J. Respir. Cell Mol. Biol. 2007, 37, 405-413. [CrossRef]

123. Li, Q.; Wall, S.B.; Ren, C.; Velten, M.; Hill, C.L.; Locy, M.L.; Rogers, L.K.; Tipple, T.E. Thioredoxin Reductase Inhibition Attenuates Neonatal Hyperoxic Lung Injury and Enhances Nuclear Factor E2-Related Factor 2 Activation. Am. J. Respir. Cell Mol. Biol. 2016, 55, 419-428. [CrossRef]

124. Dunigan, K.; Li, Q.; Li, R.; Locy, M.L.; Wall, S.; Tipple, T.E. The Thioredoxin Reductase Inhibitor Auranofin Induces Heme Oxygenase-1 in Lung Epithelial Cells via Nrf2-Dependent Mechanisms. Am. J. Physiol. -Lung Cell Mol. Physiol. 2018, 315, L545-L552. [CrossRef]

125. Ma, Q. Role of Nrf2 in Oxidative Stress and Toxicity. Annu. Rev. Pharmacol. Toxicol. 2013, 53, 401-426. [CrossRef]

126. Reiter, R.J.; Tan, D.X.; Osuna, C.; Gitto, E. Actions of Melatonin in the Reduction of Oxidative Stress. A Review. J. Biomed. Sci. 2000, 7, 444-458. [CrossRef]

127. Pan, L.; Fu, J.-H.; Xue, X.-D.; Xu, W.; Zhou, P.; Wei, B. Melatonin Protects against Oxidative Damage in a Neonatal Rat Model of Bronchopulmonary Dysplasia. World J. Pediatr. 2009, 5, 216-221. [CrossRef] [PubMed]

128. Robertson, N.J.; Martinello, K.; Lingam, I.; Avdic-Belltheus, A.; Meehan, C.; Alonso-Alconada, D.; Ragab, S.; Bainbridge, A.; Sokolska, M.; Tachrount, M.; et al. Melatonin as an Adjunct to Therapeutic Hypothermia in a Piglet Model of Neonatal Encephalopathy: A Translational Study. Neurobiol. Dis. 2019, 121, 240-251. [CrossRef] [PubMed]

129. Sampath, V.; Garland, J.S.; Helbling, D.; Dimmock, D.; Mulrooney, N.P.; Simpson, P.M.; Murray, J.C.; Dagle, J.M. Antioxidant Response Genes Sequence Variants and BPD Susceptibility in VLBW Infants. Pediatr. Res. 2015, 77, 477-483. [CrossRef] [PubMed] 